\title{
Environmental Protection in Industrial Areas and Applying Thermal Analysis to Coal Dumps
}

\author{
Rafał Jendruś* \\ Silesian University of Technology, Faculty of Mining and Geology, \\ Akademicka 2A, 44-100 Gliwice, Poland
}

Received: 6 April 2016

Accepted: 18 August 2016

\begin{abstract}
Complex analysis of thermal and gaseous states of chosen coal dumps performed by the authors made it possible to initially evaluate risk of spontaneous combustion of these objects and their classification based on indicators of a certain risk group. Thanks to the observation of coal dumps using a thermovisual camera, non-contact visualization of temperature distribution of the coal dump was obtained in the form of colored thermograms, which led to identifying areas of higher thermal activity. Use of a thermovisual camera is an example of adaptation of modern technology for research purposes. Properly planned measurement, swift development, and comparison of results gives complex information about object structure and thermal reactions on its surface. Analysis of thermal anomalies found on coal dumps allows us to draw conclusions about the causes of these events and repeating characteristics of environmental physicochemical condition variability accompanying such events.

The process of endogenic fire formation is a complex mechanism that is not yet fully understood. Doubts were dispelled in the matter of main spontaneous combustion, which is the oxidation process of coal and which is the main burning by-product material of a mining operation. However, the reason for the activation process of self-heating and leading coal substance to critical temperature $\left(60-80^{\circ} \mathrm{C}\right)$ is not fully understood. According to this, the author has reviewed knowledge related to experiences with spontaneous combustion of coal dumps.
\end{abstract}

Keywords: coal dump, thermovisual camera, spontaneous combustion, endogenic fire

\section{Introduction}

A mine is an industrial enterprise that is based on extraction of the mineral resource that we are interested in. However, there is also redundant extracted material

*e-mail: Rafal.Jendrus@polsl.pl

accompanying mined minerals, so-called gangue. Waste is created at every phase of mine development and operation, beginning with the creation of mine shafts and decks and ending with mining operation, as well as in every other technological operation that concerns enrichment of minerals brought to the surface [1]. Waste created in operation and processing of coal is called coal or mining waste. Excavation sites, due to specific conditions of coal mining in Poland, cause access mine 
workings - vertical, horizontal or sloped, that is shafts, tunnels, cross-cuts, adits, and sloping tunnels - to run through gangue and because of that all the material extracted at the time of their creation is considered waste. Currently for every one ton of extracted coal there is about 0.4-0.5 ton of waste material, which makes dumping a great amount of redundant material on the surface a necessity. Anthropogenic material that coal dumps are made of is unusual and coarse-grained, characterized by features of both coarse- and fine-grained soils. Among extracted rock fragments, shale and mudstone are the most common; the rest consist of coal slate, sandstone, and pebble conglomerates, and occasionally there are limestone and other conglomerates. Remains of coal and pyrite mixed with gangue heaped up on coal dumps can combust spontaneously in favorable conditions, which leads to long-lasting fire that is hard to control. Contents of the most important combustible components in Polish mining waste located on older dumps can reach up to $30 \%$ of coal substance and up to $8 \%$ pyrite. There are also dumps of coal slurry, created in a coal treatment process that is a waste people were once unable to use.

In past years, due to technological restrictions and undeveloped options for the use of gangue, waste was absent-mindedly gathered in random places near mines and processing plants. Decisions on where the dump should be placed have been made based on transport costs and availability of the dumping ground, with no consideration of the potential harm it may cause to the environment. Lack of waste segregation, proper grain size selection, or its density as well as failure to comply with any fire preventative measures during both building of a coal dump and after the dump has been formed are currently reasons for common spontaneous combustion in coal dumps. Smoking slopes of dumps mean that there is internal fire. Accumulation of incredibly high temperatures takes place - up to $1,200^{\circ} \mathrm{C}$. The volume of gathered material is getting reduced due to thermal transformations that cause cracking of the top of the coal dump. These cracks are zones of gas exhalation that take a toll on both the natural environment and human health [2-3].

The problem of thermal events on coal dumps is still current. In the last decade at least 21 fire occurrences were observed, mainly endogenic. It also applies to reclaimed objects [4]. The newest research performed under Cool's project (2007-13) shows the thermal activity of 15 coal dumps. It has been estimated that fire-susceptible surfaces of coal dumps constitutes $2.5 \%$ of total coal dump surface area [5-6]. At the same time, it has to be stated that in the Upper Silesian Coal Basin area there are 220 coal dumps [7-10].

Analysis of ongoing thermal activity in objects subjected to reclamation and old coal heaps created from coal mining waste leads to the conclusion about causes of thermal anomalies and repeating characteristics of environmental physicochemical conditions variability accompanying such events. The main classification factor of fire hazards of coal dumps is the scope and frequency of thermal state observation. Chronological monitoring eliminates fire risk, because any alarm event can be spotted on time and proper preventative measures can be taken [11].

In this paper particular emphasis has been placed on research related to complex analysis of thermal and gaseous states of coal dumps built from coal waste. Conclusions were drawn based on thermovisual observations, temperature measurement, and gaseous atmosphere composition inside the coal dump located in Czerwionka-Leszczyny belonging to the KWK coal mine Dębieńsko.

\section{Analysis of Coal Dumps Built from Coal Mine Waste}

Requirements associated with monitoring of deposited waste is regulated by the Ministry of the Environment act of 9 December 2002 in regards to scope, time, method, and conditions of waste dump monitoring (Dz.U. from 2002 No 220, pos. 1858). Monitoring and assessment of coal dump thermal activity include:

- Piezometer control that includes depth measurement of the water table and physico-chemical studying of these waters according to the type of deposited waste.

- Control of sewage that relies on physico-chemical studying of sewage and measurement of their amount in the time of their sampling.

- Quality control of surface water under the influence of a coal dump, relying on physico-chemical studying of waters and measurement of their amount in the time of their sampling.

- Measurement of precipitation.

- Monitoring of gaseous environments and the thermal state of the coal dump.

- Control of dump surface subsidence using surveying methods by authorized specialists based on set benchmarks.

- $\quad$ Slope stability control - geotechnical methods.

The most current solutions in regards to evaluation of the thermal state of dumps built from coal mining wastes has been shown in the method developed by the Central Mining Institute (GIG) in 2012: Method of assessing fire hazard in areas of coal mining waste deposition [12].

According to the mentioned method, the fundamental factor allowing us to classify the fire hazard of a coal dump is scope and frequency of thermal state observation. Chronological monitoring eliminates fire occurrence risk, because whenever any alarming event takes place, it is noticed in the right moment and proper steps are taken to eliminate that event.

\section{Parameters Nnecessary for Correct Evaluation of Thermal Dump Levels}

Evaluating the thermal state of a coal-mining waste dump is conducted according to parameters set by GIG based on variability of coal dump surface temperature and carbon monoxide content inside the coal dump. 
Table 1. Thermal state evaluation criteria.

\begin{tabular}{|l|c|c|}
\hline \multicolumn{1}{|c|}{ Thermal state } & $\Delta \mathrm{t}\left({ }^{\circ} \mathrm{C}\right)$ & $\mathrm{CO}(\%$ vol. $)$ \\
\hline $\begin{array}{l}\text { 1. no signs of coal } \\
\text { dump self-heating }\end{array}$ & $\Delta \mathrm{t}<3$ & $\mathrm{CO} \leq 0.002$ \\
\hline $\begin{array}{l}\text { 2. coal dump self- } \\
\text { heating }\end{array}$ & $3 \leq \Delta \mathrm{t}<10$ & $0.002<\mathrm{CO} \leq 0.015$ \\
\hline $\begin{array}{l}\text { 3. low intensity coal } \\
\text { dump fire }\end{array}$ & $10 \leq \Delta \mathrm{t}<20$ & $0.015<\mathrm{CO} \leq 0.05$ \\
\hline $\begin{array}{l}\text { 4. intensive coal } \\
\text { dump fire }\end{array}$ & $\Delta \mathrm{t} \geq 20$ & $\mathrm{CO}>0.05$ \\
\hline
\end{tabular}

$\Delta t$ is the difference between coal dump surface temperature and surrounding temperature, and $\mathrm{CO}$ is carbon monoxide concentration in a gas sample from inside the coal dump.

These parameters can also be verified during measurement. Basic criteria for thermal state evaluation are shown in Table 1.

Correction should be taken for measurements conducted in summer, as temperature of the surface may not show the real temperature inside the coal dump. It happens due to intensive sunlight. At that time, even on thermally inactive dumps, values of $\Delta t$ can well exceed $3^{\circ} \mathrm{C}$.

Sometimes, high temperatures inside a coal dump do not have to show signs of fire occurrence, because simultaneous lack of $\mathrm{CO}$ emission (averaging about $6-10 \%$ ) value of $\mathrm{CO}_{2}$ and oxygen content up to $10 \%$, indicates a fire state, which leads to cooling of deposited material [13].

\section{Technical Parameters of Instruments Needed for Research}

To conduct complex analysis of a coal dump's thermal state, according to the method created by GIG, one should use the following devices: a thermovisual camera, a pistolshaped pyrometer, and a gas analyzer [14].

Additionally, the thermovisual camera operator should be equipped with other necessary scientific gear, namely, camera, laser rangefinder, anemometer with wind speed recorder, air relative temperature and humidity recorder, a thermocouple with recorder, spare camera batteries, tripod, black, mat, and duct tape with known emissivity coefficient. Additional accessories are used to measure and record important auxiliary parameters that are necessary for measuring control of and interpreting thermograms [15].

Below are general characteristics of devices suitable for use in the temperature anomalies found on coal dumps.

1. For temperature measurement of waste material on coal dump surface:

a) thermovisual camera:

- minimal measurement range: -20 to $600^{\circ} \mathrm{C}$,

- detector: matrix 320x240 pixels or higher,

- minimal measuring accuracy: $2 \%$ size of measurement $\pm 2^{\circ} \mathrm{C}$,

- thermal sensitivity: $0.05^{\circ} \mathrm{C}$,
- Operation temperature -10 to $50^{\circ} \mathrm{C}$.

b) portable temperature measurer using infrared radiation method (pyrometer):

- measurement range: -30 to $1200^{\circ} \mathrm{C}$ or higher,

- measurement precision: $1 \%$ size of measurement \pm 1 digit,

- resolution: $1^{\circ} \mathrm{C}$ with a measuring difference of $0.1^{\circ} \mathrm{C}$,

- reaction time: about $1 \mathrm{sec}$,

- measuring cycle: minimum 4 measurement/s,

- permissible surrounding temperature: $0-50^{\circ} \mathrm{C}$.

2. For temperature measurement of waste material 0.8-1.0 $\mathrm{m}$ below an object's surface and for measurement of carbon monoxide $\mathrm{CO}$, carbon dioxide $\mathrm{CO}$, and oxygen $\mathrm{O}_{2}$ concentrations - a fumes analyzer with the following features:

- measurement ranges: for $\mathrm{CO}-0$ to $10 \%$ vol.; for $\mathrm{O}_{2}$ - 0 to $20.9 \%$ vol.; for $\mathrm{CO}_{2}$ - 0 to $25 \%$ vol.

- reading accuracy: for $\mathrm{CO} 10 \mathrm{ppm}$; for $\mathrm{CO}_{2} 0.1 \%$; for $\mathrm{O}_{2} 0.1 \%$,

- work environment temperature: from -20 to $50^{\circ} \mathrm{C}$,

- powered by built-in battery,

- resistance to harsh environments.

\section{Example of Thermal State Analysis of a Coal Dump in Czerwionka-Leszczyny}

\section{Characteristics of the Dump}

The KWK Dębieńsko coal dump is located in the area of Czerwionka-Leszczyny municipality in the Silesian Voivodeship. The object was formed for many years when the mining operation was conducted by KWK Dębieńsko. Total surface of the objects is 140 ha and covers coned coal dumps, a flat dump, and a mud sedimentation basin. On coal dumps, around $37 \mathrm{~m}$ tons of waste were deposited from mining operations, consisting mainly of rocks and coal-processing waste. Coned dumps (Fig. 1) reach heights of up to $351 \mathrm{~m}$ above sea level, while whole flat dumps and sedimentation basins range between 270 and $280 \mathrm{~m}$ above sea level and even $290 \mathrm{~m}$ in some places.

Deposition was performed using technology based on transportation of material by rail. After delivery of material to the location, it was spread by bulldozer on the coal dump with simultaneous shaping of inclination with angle of natural slopes.

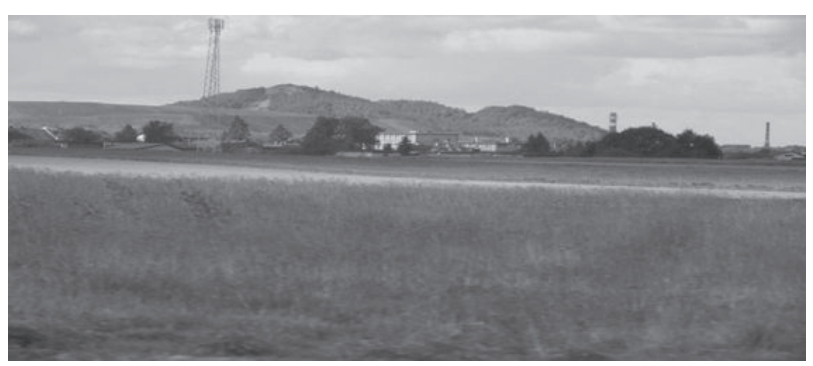

Fig. 1. I, II, and III cones from a distance [source: own]. 
The area of the dumping ground includes five cones, sedimentation basins, and a flat coal dump. Today, there are reclamation works on two cones while other cones remain untouched. Deposited on a flat dump, coarse-grained waste is subject to secondary exploitation in order to reclaim coal present in the deposited waste. The estimated percentage of coal in waste material is between $10-12 \%$. The technological procedure of coal reclamation relies on separation of coal from waste using physical methods. This technology includes crushing of deposited material, mixing, transportation, and in the end sieving using vibrating sieves, washing, desilting, enrichment in heavy medium, and finally storage of reclaimed resources (Fig. 2).

\section{Thermal State Research in Order to Localize an Experimental Field}

From February to May 2014, we conducted our own research on the Dębieńsko dump using professional equipment for measurements. Measurements were made on three cones. After preliminary overview studies, the highest thermal activity was found on cone I. In the case of cone II, only one thermally active place was found, while cone II did not show any signs of thermal activity.

During measurement in February temperature reached $0^{\circ} \mathrm{C}$, and conditions were overcast, moderate, with humidity of $85 \%$. The next studies performed at the turn of March and April were on cloudy days, when average humidity was $70 \%$ and temperature was around $10^{\circ} \mathrm{C}$.

There was deep temperature measurement on the three studied cones. A probe was placed at $15 \mathrm{~cm}$ and $1 \mathrm{~m}$ deep. Thirty measurements in total were made, which shows the biggest thermal activity on cone I. Measurement results and conclusions from research sessions will be discussed in the following chapters.

\section{Equipment and Tools Necessary for Conducting Research}

For the required measurements we used:

- IR tec MicroRay HVAC infrared thermometer (pyrometer).

- Delta OHM HD 9016 thermometer along with probes.

- Trotec ICO80V thermovisual camera.

- Hammer and chisel.

An IR tec MicroRay HVAC pyrometer was used for measuring surface temperature of the coal dump, chosen for conductions of more detailed thermal research.

Technical specifications:

- Measuring range -30 to $500^{\circ} \mathrm{C}$.

- Optics 15:1.

- Accuracy $\pm 1.5 \%$ for reading or $\pm 1.5^{\circ} \mathrm{C}$.

- Emissivity coefficient default 0.95 (set according to needs).

A Delta OHM HD 9016 thermometer along with probes was later used in studies of temperature measurement inside the object. Thanks to probes placed at depths of $1 \mathrm{~m}$ and $15 \mathrm{~cm}$, it was possible to read temperature measurements.
Technical specifications:

- Measuring range -200 to $1,800^{\circ} \mathrm{C}$.

- Precision of the device: $0-199.9^{\circ} \mathrm{C} \pm 0.1 \%$ for reading or $0.4^{\circ} \mathrm{C}$,

$200^{\circ} \mathrm{C}$ to full scale or $-0.1 \%$ to $-200^{\circ} \mathrm{C} \pm 0.2 \%$ reading, $\pm 1^{\circ} \mathrm{C}$ precision relates to environmental temperatures that are $25^{\circ} \mathrm{C} \pm 5^{\circ} \mathrm{C}$.

- Comprises two inlets for probes.

- Power (battery IEC 6LF22 9 V) $100 \mathrm{~h}$ of work.

- Weight (280 g).

Trotec ICO80V thermovisual camera used for preliminary localization of hot spots and designating their temperatures.

Technical specifications:

- Measuring range -20 to $600^{\circ} \mathrm{C}$.

- Screen refresh rate $50 / 60 \mathrm{~Hz}$.

- Geometric resolution $2.2 \mathrm{mrad}$.

- Thermal sensitivity $0.1^{\circ} \mathrm{C}$.

- Minimum measuring distance $10 \mathrm{~cm}$.

\section{Thermovisual Study}

Thermovisual study was conducted on three cones. After thermogram analysis, the highest thermal activity was demonstrated on cone I. In the case of the other two cones (I and III), activity was negligible. thanks to thermovisual camera research, places were located where areas of considerable thermal activity are visible, and places where temperature distribution did not change significantly.

\section{Comparison Analysis of Completed Thermograms}

Thermovisual studies done in four months (from February to May) proved that cone I is featured by the highest thermal activity. In February overview studies were aimed at locating hot spots. During measurement, temperature was $3^{\circ} \mathrm{C}$ while humidity of air reached $85 \%$. During measurement, the highest temperature hot spot found was $68^{\circ} \mathrm{C}$.

In March, during measurement, air temperature was $10^{\circ} \mathrm{C}$ and humidity $75 \%$. In that month, average temperature of studied thermograms was $36.6^{\circ} \mathrm{C}$. The highest measuring point temperature reached $72^{\circ} \mathrm{C}$. In April, a decrease in average temperature of measured thermograms was noted, which was $26.2^{\circ} \mathrm{C}$. This could have been caused by atmospheric conditions, as the temperature during the April measurement was $9^{\circ} \mathrm{C}$, with humidity of $60 \%$. In March it was sunny, while on the day of measuring it was completely overcast. The last measurement month on cone I was May, when temperatures during the day reached $14^{\circ} \mathrm{C}$ with humidity of $75 \%$. Although the weather was sunny, there was gusty wind which also influenced the measurement with a thermovisual camera. Average temperature of studied thermograms equaled not much less than in March, that is $35.4^{\circ} \mathrm{C}$. However, a worrying sign was observing 


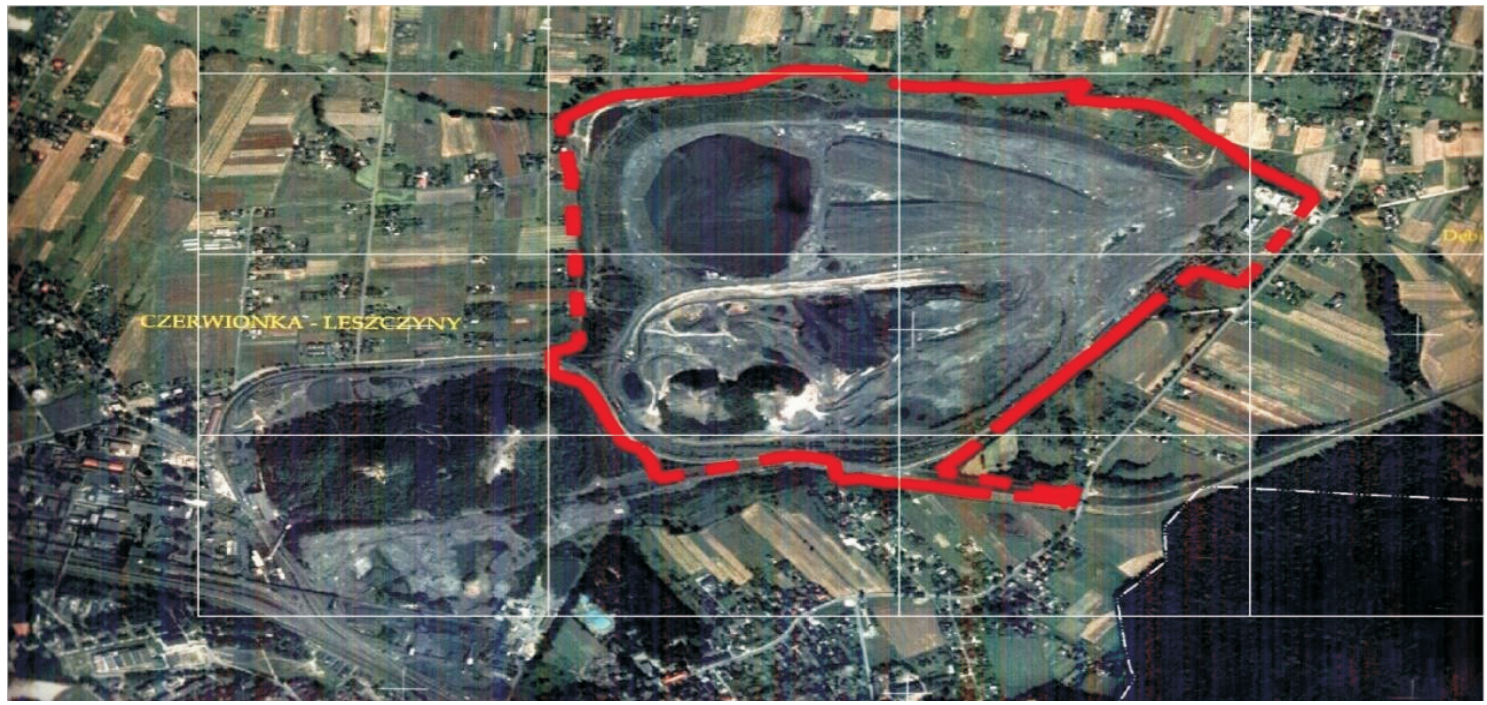

Fig. 2. Terrain map of the KWK Dębieńsko coal dump. The red line marks the area where the mining operation is performed. The yellow line marks cones in natural state [source: own].

maximum temperature on one of the thermograms, which was $85^{\circ} \mathrm{C}$.

In April research was also conducted on the second field (cone II). Studies were done in April when air temperature reached $9^{\circ} \mathrm{C}$ and humidity was at $60 \%$. There were over a dozen thermovisual measurements, which for the most part did not show that on cone II there are hot spots present. There was only one area where temperature was slightly increased. Average temperature of thermograms done in April in the area of cone II was $11.6^{\circ} \mathrm{C}$.
Also, our own research was conducted on cone III. Measurements were done in March in sunny weather at $10^{\circ} \mathrm{C}$ and $75 \%$ humidity. There were three deep measurements and several thermovisuals. Similarly, no hot spots were found in cone II. Average temperature of thermograms was $22.3^{\circ} \mathrm{C}$. The field was lacking in terms of clean foliage. In the surface there was a lot of dry wood, which heats up rapidly on sunny days and which could lead to inflated average temperatures of studied thermograms.

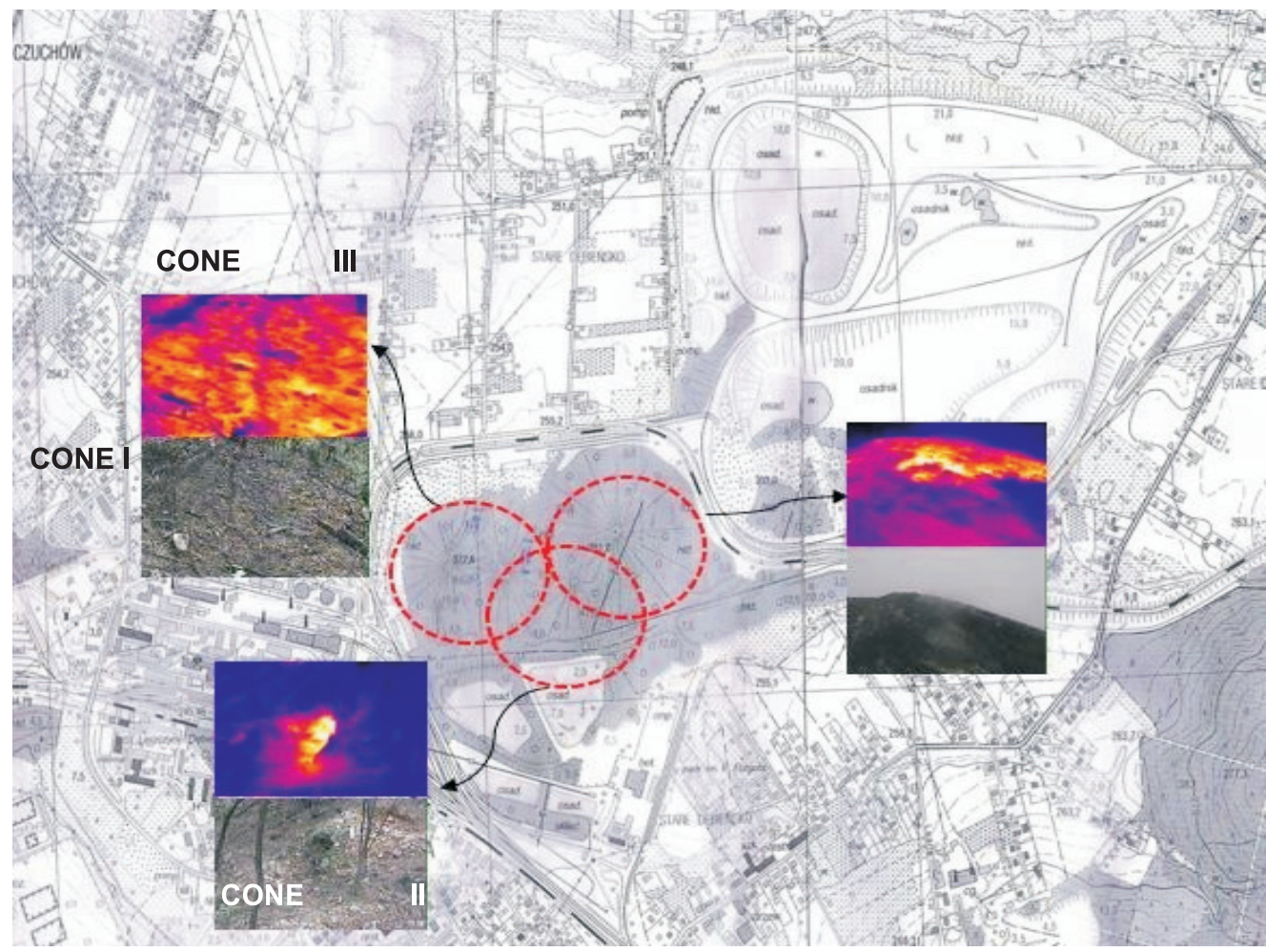

Fig. 3. Locations of areas observed using the thermovisual camera and view of exemplary thermograms [source: own]. 
After thermovisual studies were done it could be stated that cone I featured the highest thermal activity, which should be immediately controlled, while cones II and III did not show such activity.

\section{Measurement of Temperature inside the Coal Dump}

Based on our own thermovisual measurements (Fig. 3 ), deep temperature measurements also were conducted in the research area. The surface of cone I included 17 measuring holes, several of them in the same place to determine temperature changes over the course of a few months. Cone II had 5 and cone III had three holes. Fig. 4 shows locations of measuring points.

\section{First Research Field: CONE I}

Cone I is located in the northwestern part of the waste dump after the old Dębieńsko coal mine. Measurements completed using a thermovisual camera showed increased thermal activity at the top of the cone and the surface of the higher parts. Between February and May we took more than a dozen measurements of temperature inside the coal dump at depths of about $15 \mathrm{~cm}$ and over a dozen at $1 \mathrm{~m}$ deep. On certain days there were five measurements on average. Measurements in the next months were done at the same location as the previous one to determine potential changes occurring inside.

The first session was conducted in February. Field research was performed in morning hours, during complete overcast and temperature of the surrounding area of $3^{\circ} \mathrm{C}$. During measurements at $15 \mathrm{~cm}$, the highest value was recorded in the southeastern top part of cone I at $79.15^{\circ} \mathrm{C}$ with surface temperature of $59.7^{\circ} \mathrm{C}$, while the lowest value was in the southwestern top part of cone I at $42.5^{\circ} \mathrm{C}$ with surface temperature of $21.5^{\circ} \mathrm{C}$. The nest step in field research was the creation of holes ( $1 \mathrm{~m}$ deep) and readings of temperature. At depths greater than $1 \mathrm{~m}$, maximum value was found in the southeastern area of the top of cone I, where temperature reached $86.1^{\circ} \mathrm{C}$, with surface temperature of $74.1^{\circ} \mathrm{C}$. The lowest temperature was noted on the southwestern top part of the cone while in the lower part it was $58.1^{\circ} \mathrm{C}$ with surface temperature of $38.7^{\circ} \mathrm{C}$.

According to Table 1, it can be accepted that we have to deal with intense coal dump fires. The difference between maximum recorded surface temperature in measuring point and maximum temperature of coal dump surroundings $\left(3^{\circ} \mathrm{C}\right)$ was $71.1^{\circ} \mathrm{C}$.

The next month of measurement was 28 March 2014, which saw sunny weather with little overcast and a surrounding area temperature of $10^{\circ} \mathrm{C}$. Five measurements were done in the same areas as in February. Maximum value recorded by the probe was $72.3^{\circ} \mathrm{C}$, at $15 \mathrm{~cm}$, with surface temperature of $36.9^{\circ} \mathrm{C}$. Minimal value was $18.1^{\circ} \mathrm{C}$, with surface temperature of $23.7^{\circ} \mathrm{C}$. It can be observed that minimal value decreased in relation to measurements from February. In cases of increased depth measurements at $1 \mathrm{~m}$, maximum value near the top of the cone I was $82.7^{\circ} \mathrm{C}$, with surface temperature of $36.9^{\circ} \mathrm{C}$; minimal temperature recorded below the top in lower parts equaled $20.3^{\circ} \mathrm{C}$, with surrounding temperature of $23.7^{\circ} \mathrm{C}$.

According to Table 1, it can be acknowledged that we deal with intensive coal dump fires. The difference between maximum recorded surface temperature at the measuring point and maximum temperature of the coal dump surroundings $\left(10^{\circ} \mathrm{C}\right)$ was $16.9^{\circ} \mathrm{C}$.

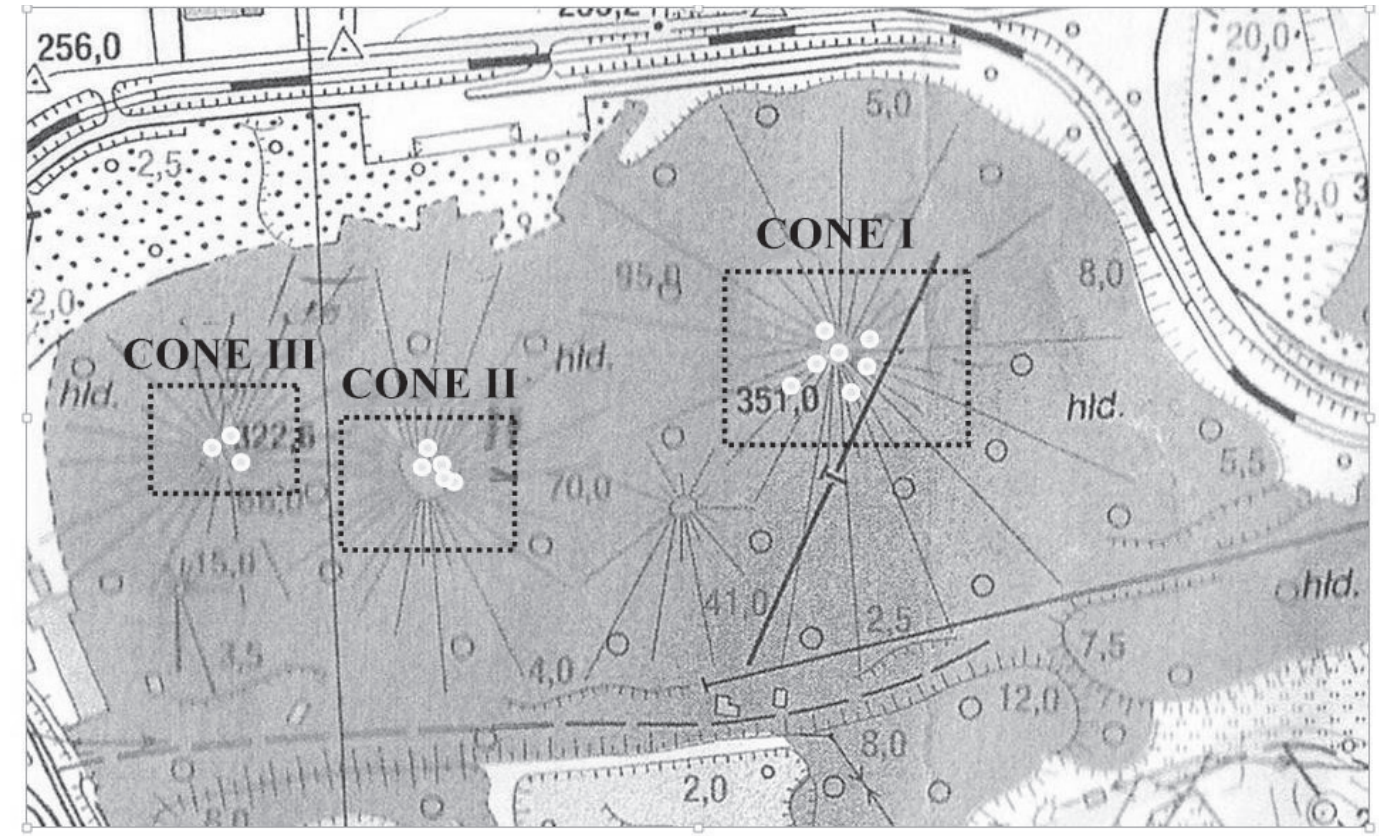

Fig. 4. Locations of boreholes on cones I, II, and III [source: own]. 
Another measurement was performed 9 April 2014 in the morning with complete overcast and a surrounding temperature of $9^{\circ} \mathrm{C}$. At a depth of $15 \mathrm{~cm}$ a probe recorded maximum temperature equal to $73.6^{\circ} \mathrm{C}$ in the southeastern area, very close to the top of the cone. The surface temperature in this area was $19.5^{\circ} \mathrm{C}$. Minimal value was observed in the lower top part of the cone and it was equal to $41.9^{\circ} \mathrm{C}$, with a surrounding temperature of $21.1^{\circ} \mathrm{C}$. After increasing depth to $85 \mathrm{~cm}$, maximum value near the top was $78.1^{\circ} \mathrm{C}$, with surface temperature of $25.5^{\circ} \mathrm{C}$. Minimal value equaled $51.2^{\circ} \mathrm{C}$, with surface temperature of $21.1^{\circ} \mathrm{C}$.

According to chapter 5.5 it can be accepted that we deal with low intensity coal dump fires. The difference between maximum recorded surface temperature in the measuring point and maximum temperature of the coal dump surroundings $\left(9^{\circ} \mathrm{C}\right)$ was $25.5^{\circ} \mathrm{C}$. Weather conditions on the day before measurement should be taken into consideration. On 8 April in the area of the dump there was some low-intensity precipitation that could have caused temporary cooling of the surface of the dump.

The last measurement was 10 May, when the surrounding temperature was $13^{\circ} \mathrm{C}$ with partial overcast. On this day we took a few more measurements than in previous months in order to obtain even more detailed data about the thermal state of cone I. The measurement of the top of cone I was done in a place where the highest temperatures were recorded both in cases of $15 \mathrm{~cm}$ probe as well as the $1 \mathrm{~m}$ probes. Maximum temperature at $15 \mathrm{~cm}$ reached values of $85.8^{\circ} \mathrm{C}$, and for the $1 \mathrm{~m}$ probe $88.3^{\circ} \mathrm{C}$. Temperature of the surface near these holes was at $36^{\circ} \mathrm{C}$. Minimal values were recorded in the eastern part of cone I and the lower parts of the top. With surface temperature of $33.6^{\circ} \mathrm{C}$, a shorter probe recorder temperature equal to $42.5^{\circ} \mathrm{C}$ and a long one of $45.5^{\circ} \mathrm{C}$.

According to Table 1 it can be acknowledged that there is an intensive coal dump fire, with the difference between maximum recorded surface temperature in the measuring point and maximum temperature of the coal dump surroundings $\left(13^{\circ} \mathrm{C}\right)$ of $23.4^{\circ} \mathrm{C}$. The above description is shown in Fig. 6.

Cone I is a place often visited by people riding bikes (Fig. 5). Fans of motorsports, riding on top of the coal dump, uncover the surfaces that oxygen can access, thus fueling the fire raging inside. An unpleasant smell emanates from open measuring holes.

\section{Second Research Field: CONE II}

Another area covered by thermal studies was cone II, which is located near cone I (from the southwestern side). This area was not subject to fire zones as intensive as cone I, which is why in this zone only overview studies were conducted. In the case of studies done with a thermovisual camera in the area of cone II, only one place was located where the thermal state was high and where exhalation of gas occurred. According to Table 1 it was accepted that in the second area there is self-heating of the coal dump but it can't be said that there is fire. The difference between maximum recorded surface temperature in measuring point and maximum temperature of the coal dump surroundings was $4.5^{\circ} \mathrm{C}$. The above description is shown in Fig. 7.

\section{Third Research Field: CONE III}

The last object where studies of thermal state were conducted was cone III, located in the line of the last two cones. Although deep measurements performed in this area excluded the presence of hot spots (Fig. 8), this was unclear in the preliminary stage.

If one would follow only the data shown by thermograms, the conclusion could be made that the coal dump surface shows signs of thermal anomalies. However, from the start there was a belief that thermal images may be biased. Reasons for biased measurement can be found in weather conditions. Pictures were taken during sunny weather that caused self-heating of waste material on the top of the cone (Fig. 9). Additionally, in the measurement area a lot of wooden material could be found that heated up when exposed to the sun, inflating the real temperature of an object and in turn inflating the thermovisual camera measurements.

It is understood that the thermovisual camera operator cannot be limited only to the operation of equipment and creating thermograms; the general task includes complete and profound interpretation of thermal imaging and the formulation of conclusions and recommendations. This is why recommendations and procedures should be followed.

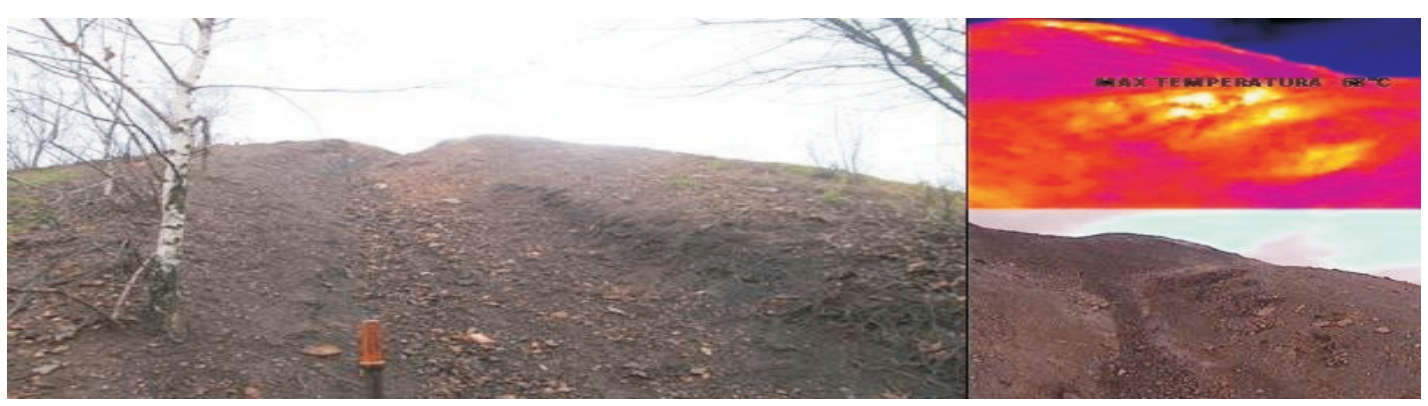

Fig. 5. Motorsport and cycling practices on the dump leads to the creation of erosion trenches, which help provide oxygen to waste mass that is necessary for self-heating processes [source: own]. 


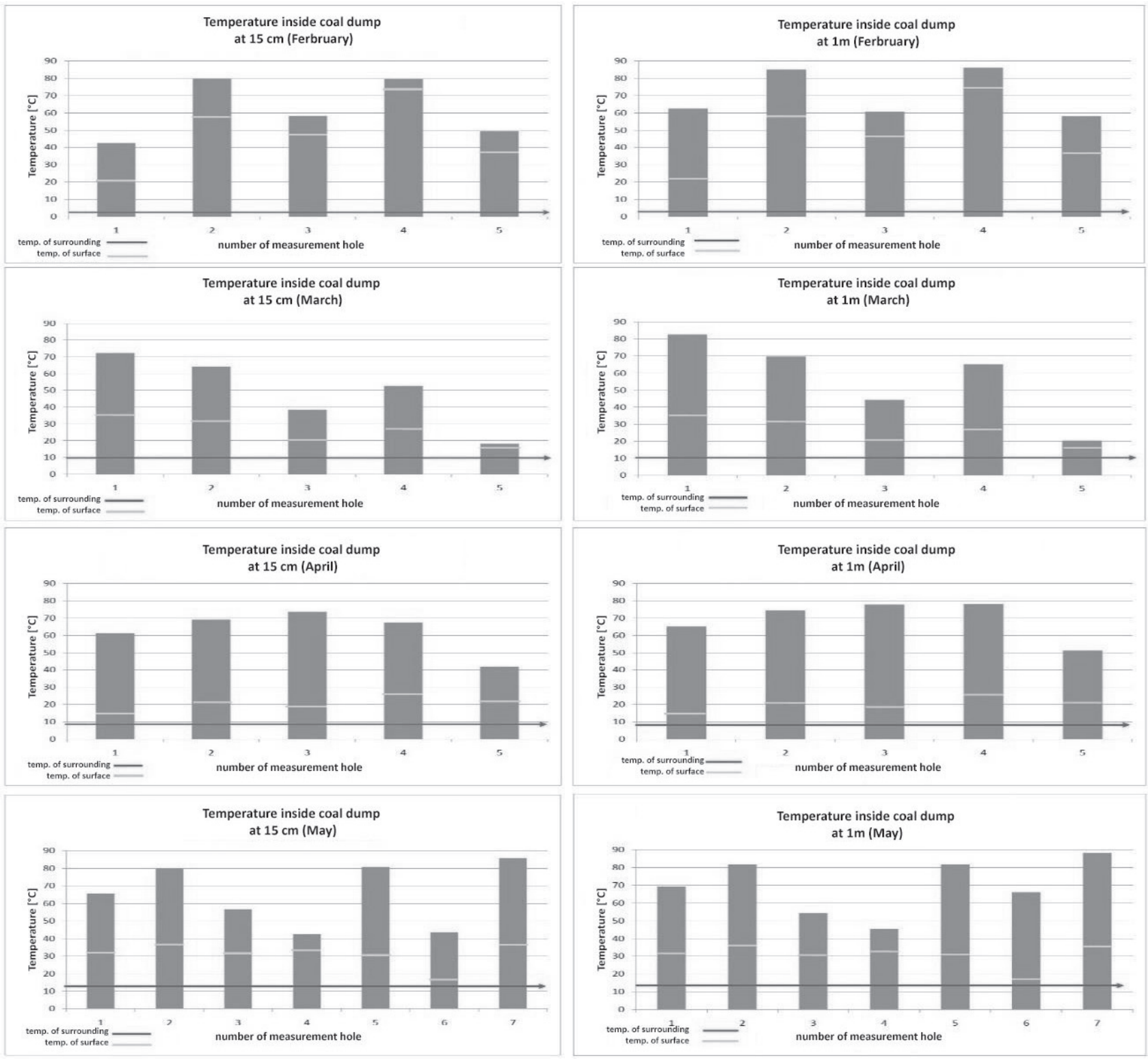

Fig. 6. Temperature analysis of the inside of the KWK Dębieńsko mine waste dump at depths of $15 \mathrm{~cm}$ and $1 \mathrm{~m}$. The research field covers the area of cone I. Measurements registered between February and May were taken into account [source: own].

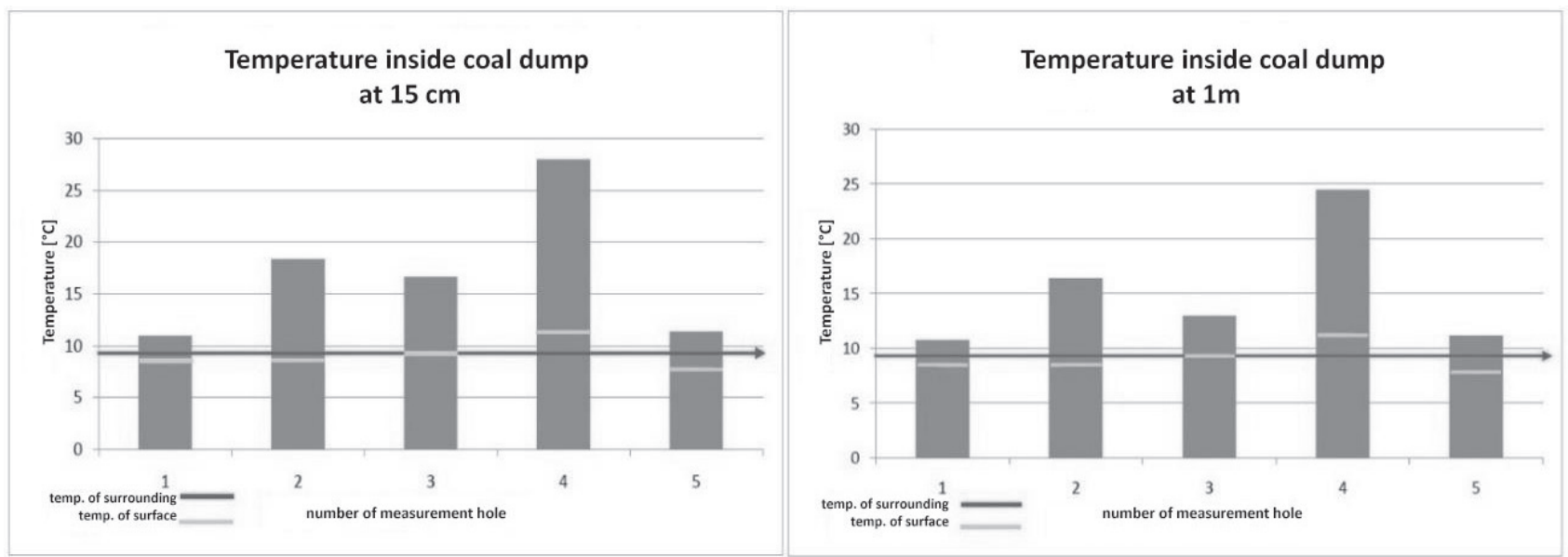

Fig. 7. Temperature analysis of the inside of the KWK Dębieńsko mine waste dump at depths of $15 \mathrm{~cm}$ and $1 \mathrm{~m}$. The research field covers the area of cone I. Measurements registered in April were taken into account [source: own]. 

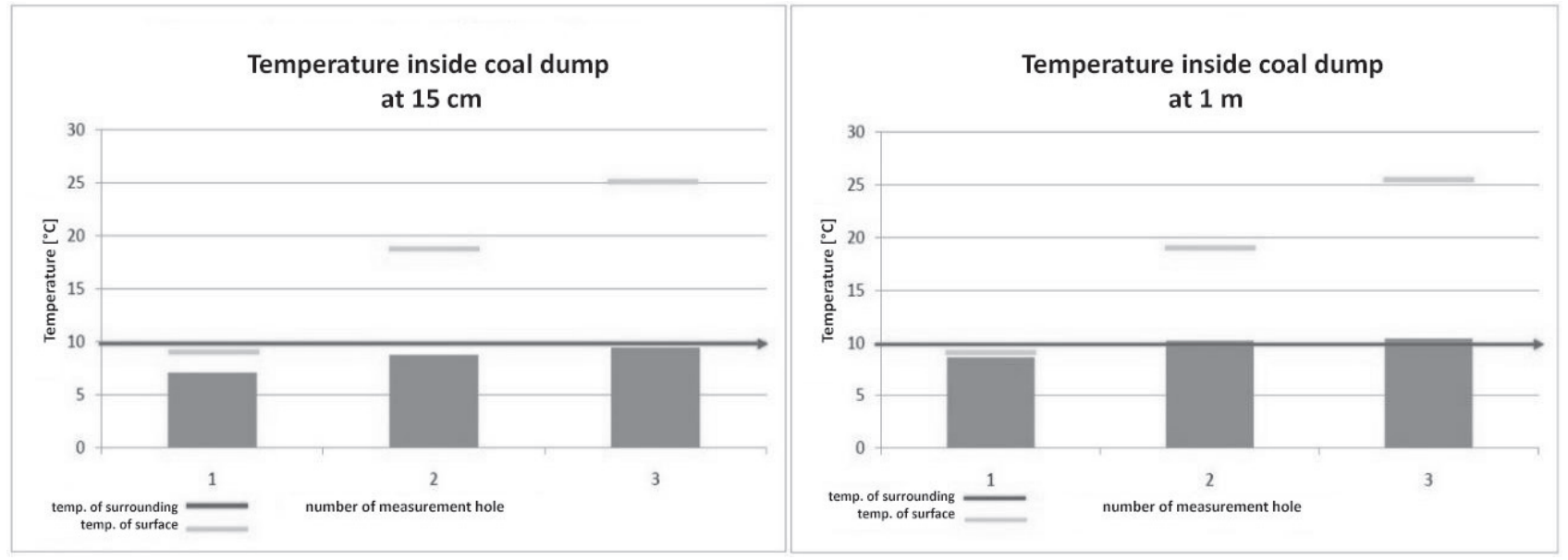

Fig. 8. Temperature analysis of the inside of KWK Dębieńsko mining waste dump at a depth of $15 \mathrm{~cm}$ and $1 \mathrm{~m}$. The research field covers the area of cone I. Measurements registered in March were taken into account [source: own].

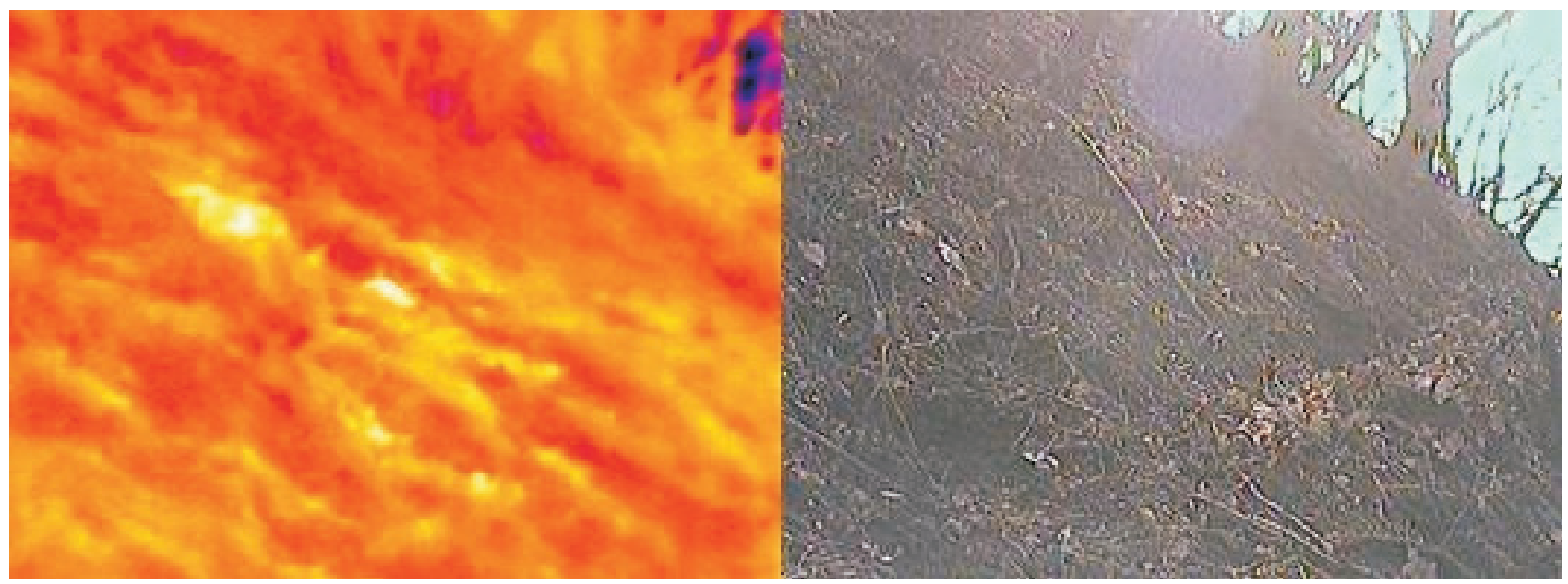

Fig. 9. Sunrays during a cloudless day heat up the surface of the dump, preventing the preparation of accurate thermograms [source: own].

\section{Conclusions}

1. Highly combustible substances deposited in waste in the KWK Dębieńsko coal dump in CzerwionkaLeszczyny can become a constant fire hazard.

2. The difference of temperature between the coal dump surface and the surroundings in the first research field (cone I) showed signs of an intense fire as the temperature inside cone I reached, in places, $89^{\circ} \mathrm{C}$.

3. The difference of temperature between coal dump surface and the surroundings in the first research field (cone II) showed signs of self-heating of deposited material. The temperature inside cone II reached, in some measuring points, $25^{\circ} \mathrm{C}$.

4. Thermovisual camera measurement proved that cone III is subject to low-intensity fire; however, measurements of the inside of the dump excluded such a possibility. Maximum recorded value equaled $10.4^{\circ} \mathrm{C}$
5. The necessary preventative action range that should be undertaken is to apply surveillance. It is also needed to start working on condensation of dumps, especially in places where fissures show up. Beneficial operation would be securing the dump by putting signs or enclosing the area. It would reduce to a minimum participation in motorsports on the coal dump, which creates erosion trenches on the slopes.

\section{References}

1. KLETA H. Geotechnical hazards in coal dumping ground areas [Zagrożenia geotechniczne w obrębie składowisk odpadów pogórniczych]. Mining and Geology [Górnictwo i Geologia] 1 (6), 2011 [In Polish].

2. KUNA P., ŁĄCZNY J.M. PAHs hazards in workplace environment during deconstruction of coal dumps. [ $\mathrm{Za}$ grożenie środowiska pracy związkami WWA podczas prac rozbiórkowych składowisk odpadów powęglowych], 
Polish Geological Institute Bulletin 450, 57, 2012 [In Polish].

3. KUNA-GWOŹDZIEWICZ P. Polycyclic aromatic hydrocarbons in gas exhalation zones of chosen, themally active coal mining waste dump [Zagrożenia geotechniczne w obrębie składowisk odpadów pogórniczych], J. Sust. Min. 12 (1), 7, 2013 [In Polish].

4. ZAJĄC E., ZARZYCKI J. Influence of thermal activity of coal dump on development of flora [Wpływ aktywności termicznej zwałowiska odpadów węgla kamiennego na rozwój roślinności] University of Agriculture, Kraków 2013 [In Polish].

5. www.cools.pl

6. Joint work edited by Łączny J.M., Baran J., Ryszko A. Development and implementation of innovative environmental techno-logies used on coal dumps. Theory and methodology basics and practical examples [Opracowanie i wdrażanie innowacyjnych technologii środowiskowych stosowanych na zwałowiskach odpadów powęglowych. Podstawy teoretyczno- metodyczne i przykłady praktyczne]. GIG, Silesian University of Technology, Institute of Mining Mechanisation - PIB, Radom 2012 [In Polish].

7. FABIAŃSKA M., CIESIELCZUK J., KRUSZEWSKI Ł., MISZ-KENNAN M., BLAKE D., STRACHER G., MOSZUMAŃSKA I. Gaseous compounds and efflorescences generated in self-heating coal-waste dumps A case study from the Upper and Lower Silesian Coal Basins (Poland). International Journal of Coal Geology 116, 2013.

8. MISZ-KENNAN M., FABIAŃSKA M.J. Thermal transformation of organic matter in coal waste from Rymer Cones (Upper Silesian Coal Basin, Poland), Int. J. of Coal Geol., 81, 343, 2010.

9. MISZ-KENNAN M. Thermal alterations of organic matter in coal wastes from Upper Silesia, Poland, Mineralogia, 41, 105, 2010.
10. SKRĘT U., FABIAŃSKA M.J., MISZ-KENNAN M. Simulated water-washing of organic compounds from selfheated coal wastes of the Rymer Cones Dump (Upper Silesia Coal Region, Poland). Organic Geochemistry, 41, 1009, 2010

11. CEBULAK S., ŚMIEJA-KRÓL B., TABOR A., MISZ M., JELONEK I., JELONEK Z. Oxyreactive Thermal Analysis (OTA) - useful and cheap method of evaluation of spontaneous combustion of coals risk on dumping grouns - initial research results [Oksyreaktywna Analiza Termiczna (OTA) - dobra i tania metoda oceny samozapalności węgli na składowiskach - wstępne wyniki badań]. Geology and problems of environment protection in Upper Silesian region, Conference materials of LXXVI Scientific Meeting of Polish Geological Society [Geologia i zagadnienia ochrony środowiska w regionie górnośląskim, materiały konferencyjne LXXVI Zjazdu Naukowego Polskiego Towarzystwa Geologicznego]. Rudy near Rybnik, 14-16 September 2005.

12. GOGOLA K., BAJERSKI A., SMOLIŃSKI A. Modification of fire hazard evaluation method in areas of coal waste deposition [Modyfikacja metody oceny zagrożenia pożarowego na terenach lokowania odpadów powęglowych], Scientific Works GIG, Mining and Environment 2, 2012 [In Polish].

13. PIKON K., BUGLA J. Emission from reclaimed conical dumping grounds [Emisja ze zrekultywowanych zwałowisk stożkowych]. Archives of Waste Management and Environmental Protection 6, 55, 2007 [In Polish].

14. CARPENTIER O., DEFER D., ANTCZAK E. Infrared thermography applied to spontaneous combustion monitoring of coal tips, QIRT Archives, 2004.

15. NOWAK H. Utilization of thermovisual measurements in construction sector [Zastosowanie badań termowizyjnych w budownictwie]. Publishing of Wrocław University of Technology, Wrocław 2012 [In Polish]. 